\title{
視覚の誘導場による読み易い和文文字列表示
}

\section{Legible Display of Japanese Characters based on Induction Field in Vision}

\author{
正会員 長 石 道 博 \\ Michihiro Nagaishi ${ }^{\dagger}$
}

\begin{abstract}
The induction field in vision can be an index for legible display of Japanese characters. The traditional display is based on types of characters, character size and the distance between characters. There is no method, however, that provides an index for the legible display of any types of characters. It was suggested recently that the interaction in the induction field by characters relates to the legibility of characters. It is thought that the strength of the induction field which surrounds each character may be an index for the legibility of characters. To confirm this theory psychological experiments were done. This paper describes these tests and it is confirmed that the strength of the induction field can be an index for the legibility of characters.
\end{abstract}

キーワード：文字列表示, 読み易さ, 視覚の誘導場, 閉曲線

\section{1. まえがき}

文字の大きさや間隔などを調整して，文字列を読み易く 表示する一般的な方法が明らかにされていない１つ1つ の文字自体が読み易い条件はこれまで数多く明らかにされ ている。例えば，活字の場合，書体のデザイン1)2)，紙とイ ンキの明度差 ${ }^{2)}$, 可読性と文字の大きさの関連性 ${ }^{23)}, 2$ 值 よりも階調のある文字が読み易い4) な゙が明らかにされて いる．文字列の場合，文字種・文字の大きさ・文字間隔な どを調整することによって，文字列が読み易くなると考え られており，例えば，仮名は漢字より間隔を詰めても読み 易いなどの傾向が示されている ${ }^{5)}$ 。また，一般に和文印刷 では，文字間隔を文字幅の約半分に設定，句読点など一部 の文字の間隔を詰めることが多( ${ }^{6)-8)}$ 。このように，特定 の文字種を中心とした文字間隔の詰め方など，主観的に決 められた文字列表示の経験則が存在する。しかし，任意の 文字種について, どのくらいの大きさの文字をどのくらい 間隔を詰めても読み易いかなどを決める定量的な評価方法 は，ほとんど明らかにされていない8)。したがって，読み 易い和文の文字列表示を実現するには，任意の文字種につ いて，読み易い文字の大きさ，文字間隔を定量的に導き出 す基準や方法を検討する必要がある。

さて，文字列内の個々の文字が読み易い状態とは，個々

1997 年 12 月 5 日, 映像情報メディア学会冬季大会, $7-3$ に発表

1998 年 4 月 1 日受付, 1998 年 9 月 4 日再受付, 1998 年 10 月 6 日採録 †セイコーエプソン株式会社

（テ 392-8502 諏訪市大和 3-3-5, TEL 0266-52-3131）

$\dagger$ SEIKO EPSON Corporation

(3-3-5, owa, Suwa-shi, Nagano 392-8502, Japan)
の文字が醸し出している文字の周囲に波及する視覚の誘導 場9が，できるだけ干渉しないような間隔で文字が配置さ れていることが示唆されている10)。そして，個々の文字を 囲む誘導場の閉曲線が存在し，そのポテンシャル值が高い と他の文字との分離が難しく，読みにくいことが示唆され ている ${ }^{11)}$.また，図形の配置が均整かどうか誘導場を用い

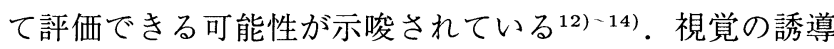
場の存在は心理学実験結果から妥当性が確認されており ${ }^{15)}$, 錯視 ${ }^{16)}$ やパターン認識15)などの人間の視覚特性が説明でき る視知覚の概念である。このことから，誘導場の分布を基 準にすれば，人間が判断する文字列の読み易さを定量的に 評価できると考えられる，そこで，本論文は最初に文字種， 文字の大きさ，文字間隔が異なる日本語の文字列に扔ける 個々の文字を囲む誘導場の閉曲線の強さが，人間が判断す る文字列の読み易さと関連するか調へ，文字列の読み易さ の指標としての妥当性を検証する，次に，文字列の誘導場 の閉曲線の強さは，個々の文字が単独に存在する場合の誘 導場の分布から計算により予測できることを示す。

\section{2. 文字列における視覚の誘導場}

\section{1 視覚の誘導場の計算方法}

ディジタル画像の視覚の誘導場は, パターンの外郭を構 成する画素を点電荷と仮定し，それらがつくるクーロンポ テンシャルの集積から計算する ${ }^{15)}$. 図 $\mathbf{1}(\mathrm{a})$ のように $n$ 個 の点列から構成される曲線 $f(s)$ によって点 $\mathrm{P}$ に誘導場が 形成されるとする．曲線を構成する各点を正電荷 1 の点電 荷と仮定, 点 $\mathrm{P}$ から曲線 $f(s)$ 上の点 $i$ までの距離を $r_{i}$ と する．点 $\mathrm{P}$ の誘導場の強さ $M_{p}$ を次のように定義する. 


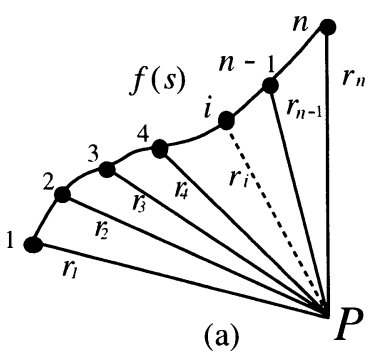

(a)

図 1 ディジタル妯像における視覚の誘導場 Induction field on digital image.

$$
M_{p}=\frac{1}{n} \sum_{i}^{n} \frac{1}{r_{i}}
$$

図 1(b) は (1) 式を用いて計算した「あ」の誘導場の例であ る.「あ」周辺に地図の等高線状に分布しているのが誘導場 の等ポテンシャル線で，中央から外に行くほど誘導場は弱 くなる。なお，(1) 式は点 $\mathrm{P}$ から発した光が当たる部分の み和をとる制約条件がつくので注意が必要である15).

\section{2 文字列の視覚の誘導場の分布と文字配置}

複数の文字で構成された文字列の誘導場の分布と文字 配置の関係を検討する. 現在, 和文書の大半は横書き文書 で，縦書きははがきや文芸などに限られることが多いため， 本論文では横書きの文字列について検討する，最初に，図 2(a) の文字列「もやゆよ」の例のように上下に別の文字 列がなく, 一文字列が単独で存在し個々の文字が接触しな い文字列について検討する. 図 2 は文字列「もやゆよ」が つくる視覚の誘導場を, 図 2(a) はポテンシャル值 0.013 , (b) は 0.031, (c) は 0.053, (d) は 0.067 のうに徐々に大 きくした場合について示した例である，ポテンシャル值が 低い図 2(a) の場合，文字列全体を包絡線のように囲む閉 曲線 $\mathrm{A}$ が存在する．ポテンシャル值が大きくなると，ま ず図 2(b) のように「も」のみ囲む閉曲線 $\mathrm{B}_{1}$,「やゆよ」を 囲む閉曲線 $\mathrm{B}_{2}$ が出現する（ポテンシャル值 $\alpha$ 0.031）。さ らにポテンシャル值が大きい図 2(c) の場合,「やゆ」を囲 む閉曲線 $\mathrm{C}_{2}$ と「よ」のみを囲む閉曲線 $\mathrm{C}_{3}$ が出現する（ポ テンシャル值 $\beta$ 0.053) . 最後の図 $2(\mathrm{~d})$ の場合,「や」「ゆ」 をそれぞれ囲む閉曲線 $\mathrm{D}_{2}, \mathrm{D}_{3}$ が出現する（ポテンシャル 值 $\gamma$ 0.067）. 個々の文字を囲む閉曲線のポテンシャル值は 文字間隔によって異なっている。例えば「も」は,「や」と 「ゆ」の間隔に比べ「や」と離れているので, 低いポテン

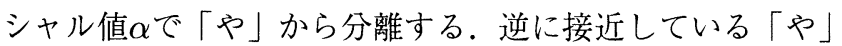

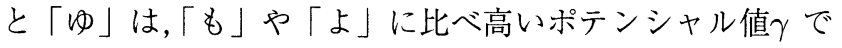
ないと分離しない. 図 2 の例を含め他の文字列の誘導場 の分布の観察から，文字間隔が狭く読みにくいと文字列を 構成する個々の文字を囲む閉曲線が最初に出現する際のポ テンシャル值は高くなる.すなわち, 文献 11) で示唆され たように，文字の間隔によって誘導場の干渉の強さに違い が生ずる。その違いは文字列を構成する個々の文字が分離 する誘導場の閉曲線の強さで表されると考えられる。例え (a)

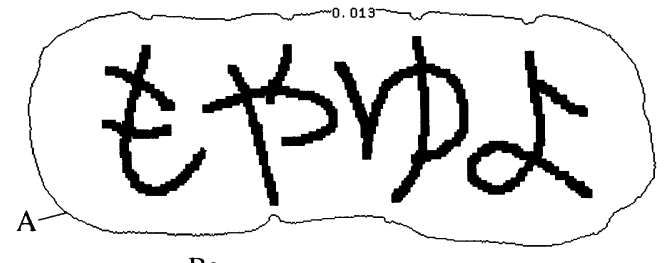

(b)

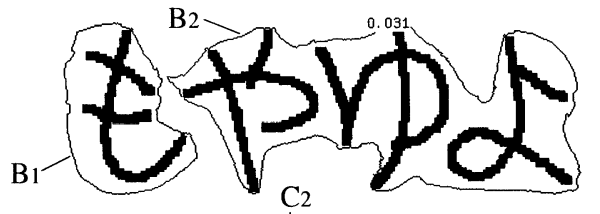

(c)

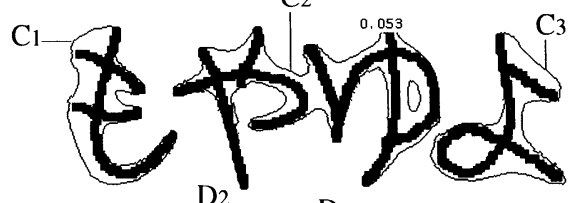

(d)

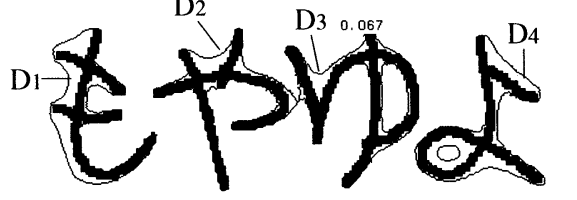

図 2 文字列における視覚の誘導場 Induction field created by characters.

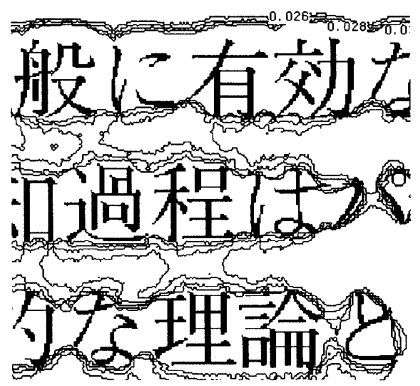

(a)

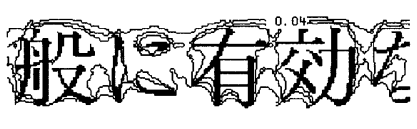

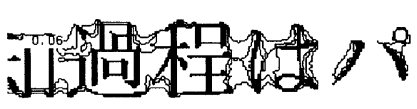

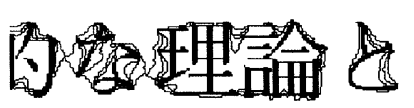

図 3 複数の文字列による誘導場 Induction field by lines.

ば, 図 2 の場合, 3 つのポテンシャル值 $\alpha, \beta, \gamma$ の平均 を文字列「もやゆよ」の読み易さの指標に使うことができ る. 一般に $n$ 個の文字から構成される文字列の隣接する $i$, $i+1$ 番目の文字が最初に分離する誘導場の閉曲線のポテン シャル值を $x_{i}$ とすれば, 文字列全体の読み易さは, 次のポ テンシャル值の平均 $\bar{M}$ を用いて評価できると考えられる.

$$
\bar{M}=\frac{1}{n-1} \sum_{i}^{n-1} x_{i}
$$

\section{3 複数の文字列による誘導場の分布}

続いて, ある文字列の誘導場の分布に, 上下に存在する 他の文字列が及ぼす影響を検討するため，印刷に近いコン ピュータ組版の和文 $\mathrm{IAT}_{\mathrm{E}} \mathrm{X}^{7}$ で作成した複数の文字列を含 む画像 $(320 \times 320$ ドット, $72 \mathrm{DPI})$ の誘導場を計算し, 図 2 のようにポテンシャル值を徐々に大きくしながら, 各文 字列を包絡線のように囲む誘導場の分布と, 各文字列内の 個々の文字が分離する誘導場の分布を比較した例を図 3 に 示す．図 3 の例を含め，まず図 $3(\mathrm{a})$ の文字列「般に有効 
な」「知過程はパ」「的な理論と」のように各文字列を囲む 誘導場がポテンシャル值 0.02 0.03 程度で現れ, さらにポ テンシャル值が 0.04 程度以上になると, 図 3(b) の文字列 「知過程はパ」の「パ」,「的な理論と」の「と」「な」などの ように文字列内の個々の文字が分離する。このように，文 字列が複数の場合, 各文字列の分離と文字列内の個々の文 字の分離は別々に扱うことができるので，分離した各文字 列について, 図 2 の要領で (2) 式による文字列の読み易さ を評価できると考えられる。そこで，本論文では文字列の 読み易さは, 図 2 のような単一の文字列について検討する.

\section{3. 文字列の読み易さと誘導場の関連性の検証}

(2) 式による誘導場の強さが，人間が判断する文字列の 読み易さを説明できることを検証する，本論文では，いろ いろな文字種, 文字の大きさ, 文字間隔をもつ文字列を被 験者に呈示して, 読み易さを 5 段階評価してもらった心理 実験結果と (2) 式による誘導場の強さの相関を調べた.

最初に, 文字の読み易さの心理実験方法を述べる. 文字 列が単語や熟語を含む場合, 可読性が高くなる単語優位効

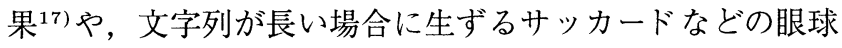

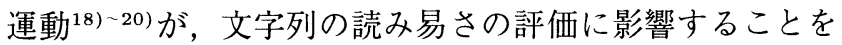
避けるため, 眼を動かさず一目で認識できる日本語の文字 数の範囲 ${ }^{18)}$ である 5 文字で構成した, 熟語を含まない無意 味な文字列を呈示した，そして，日本語文書の読みに関す る心理実験では, 視角を 1 文字あたり $1^{\left.\left.{ }^{\circ} 18\right) 20\right)}$ から $2^{\left.{ }^{\circ} 19\right)}$ 程 度に設定すると被験者が読み易いことから, 呈示する 1 文 字あたりの視角を 2 ○に設定した。

被験者に呈示した 3 種類の文字列の基本型を図 4 に示 す. 図 4(a) はすべて仮名, 図 4(b) はすべて漢字, 図 4(c) は仮名漢字混じりの無意味な文字列である。これらは, Macintosh 上で図 5(a)のように一辺の長さが 60 ポイン 卜（72DPI）の正方形 5 個を間隔 $0 \mathrm{~mm}$ で並べ，それぞれ の正方形に正方形の一辺の長さと同じポイント数の Osaka フォントの文字を, 文字の重心と文字が外接する正方形の 中心を合わせて配列した $\left(1\right.$ ポイント $\left.=0.3514 \mathrm{~mm}^{2)}\right)$. 以 降の実験も解像度, 文字のフォントはすべて同じである。 図 4 の 3 つの各基本文字列について, 文字の大きさ, 文字 間隔を変更した文字列を用意する。まず，図 $5(\mathrm{a})$ と同じ要 領で，文字の大きさを基本状態（60 ポイント）の他に 56 , 52 ポイントの文字列を構成する.ささらに, これら大きさの 異なる 3 種類の文字列について, 文字間隔 $0 \mathrm{~mm}$ の基本状 態の他に, 図 5(b)のように文字間隔を各文字の間隔を 1 $\mathrm{mm}$ 広げる, または $1,2 \mathrm{~mm}$ 詰める。このように, 図 4 の 1 つの基本文字列について，3 種類の文字の大きさ $(60$, 56,52 ポイント ), 4 種類の文字間隔 $(-2,-1,0,1 \mathrm{~mm})$ の 12 種類, 合計 36 個の文字列を準備した。 なお，図 4(c)

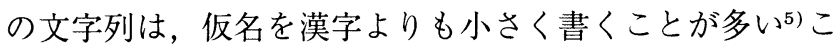
とを考慮して,「晴」のみは大きさ 60 ポイントの外接正方 形のまま, 他の仮名の外接正方形の大きさを変更した．図
ねすにれそ塩歩晴具堅 ねす晴れそ

(a)

(b)

(c)

図 4 是尗し文字列

Examples of characters to subjects.

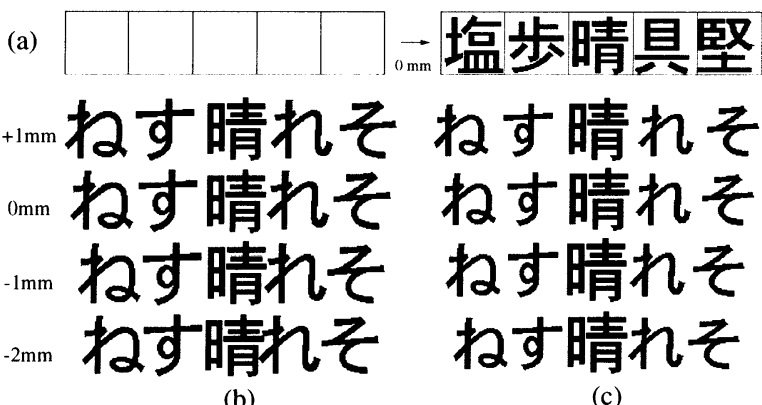

図 5 文字の配置と文字列の变更

Location of characters and various samples of characters.

5(c) は，図 4(c) の文字列を仮名の大きさを 52 ポイントに して文字間隔を変更した例である.

以上のように作成した文字列を，自発光する CRT と反 射光を用いる紙の代表的な 2 種類の方法で, 視力が健常な 20 歳代の男子大学院生 19 名の被験者に呈示した. CRT は Apple 社の Macintosh 用 12 インチカラーモニタ, 紙は文 字列を印刷したボードを使用した．CRT, 紙共に白背景に 黒文字である. 各方法共に文字列を 1 文字 $(60$ ～52 ポイン 卜）の視角が $2^{\circ}$ 程度になる視距離 $1.0 \mathrm{~m}$ で呈示する. 呈 示方法による視距離や被験者の姿勢を変化させないため, $\mathrm{CRT}$ と紙の文字列の位置が一致するようボードは CRT の 直前に置き，被験者の顔を顎台に固定した，実験中，暗幕 で外光を遮断して照明条件を一定に保った，そして，文字 種，文字の大きさ，文字間隔の異なる 36 個の文字列をラ ンダムに呈示し，時間制限をせずに各文字列の読み易さを， 非常に読み易い 5 , 読み易い 4 , 普通 3 , 読みにくい 2 , 極 めて読みにくい 1 の 5 段階の絶対評価を口頭で報告して もらった。これを光源別に行った。評価は, 文字列の 1 文 字 1 文字が何であるか認識するのがどの程度大変に感じる か評価してもらう，読むのが大変に感じるほど数字が低く $(2 ， 1)$, 容易なほど数字は高い $(4,5)$. 例えば, 文字間隔 が充分広い場合, 各文字の認識が容易で読み易い評価にな ると考えられる。ただし, 文字間隔が充分あって文字自体 は読み易いが，文字間隔が余り広いのは嫌いだから読みに くいなどの個人の嗜好は, 読み易さの評価に含めないよう 指示した。事前に図 4 とは文字種が異なる文字列を呈示し て評価基準の説明, 理解した後, 本実験を行った。

次に, 心理実験に使用する 36 個の文字列を文字列の長 さに応じて, $256 \times 256$ または $320 \times 320$ ドットの文字画 像に変換, (1) 式を用いて誘導場を計算した。 そして, 図 2 と同様の要領で, ポテンシャル值を 0.001 ずつ徐々に大 きくした誘導場の分布を観察, $i$ 番目の文字を囲む誘導場 


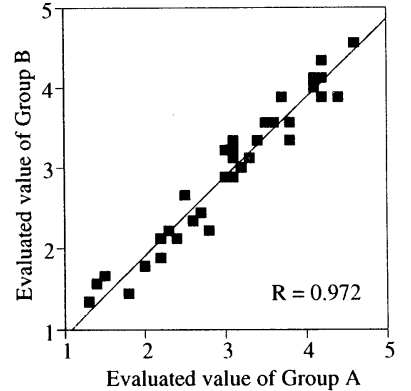

(a)

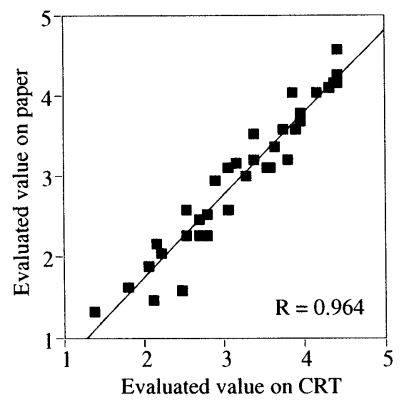

(b)
図 6 検証結果 (1)

Examing results (1)

表 1 心理学実験結果

Psychological experiment results.

\begin{tabular}{l|c|c|c|c}
\hline \hline \multicolumn{5}{c}{ ねす扎そ } \\
\hline distance & $-2 \mathrm{~mm}$ & $-1 \mathrm{~mm}$ & $0 \mathrm{~mm}$ & $1 \mathrm{~mm}$ \\
\hline 60 point & $2.47(1.58)$ & $2.53(2.26)$ & $3.05(3.11)$ & $3.89(3.58)$ \\
\hline 56 point & $2.68(2.26)$ & $3.16(3.16)$ & $3.89(3.58)$ & $4.32(4.11)$ \\
\hline 52 point & $3.63(3.37)$ & $4.16(4.05)$ & $4.42(4.26)$ & $4.42(4.58)$ \\
\hline \multicolumn{5}{c}{ 塩歩晴具堅 } \\
\hline 60 point & $1.37(1.32)$ & $2.21(2.05)$ & $2.68(2.47)$ & $3.26(3.00)$ \\
\hline 56 point & $2.11(1.47)$ & $2.79(2.53)$ & $3.37(3.21)$ & $3.74(3.58)$ \\
\hline 52 point & $3.05(2.58)$ & $3.58(3.11)$ & $3.84(4.05)$ & $4.42(4.16)$ \\
\hline \multicolumn{5}{|c|}{ ねす晴にそ } \\
\hline 60 point & $1.79(1.63)$ & $2.16(2.16)$ & $2.89(2.95)$ & $3.79(3.21)$ \\
\hline 56 point & $2.05(1.89)$ & $2.53(2.58)$ & $3.37(3.53)$ & $3.95(3.79)$ \\
\hline 52 point & $2.79(2.26)$ & $3.53(3.11)$ & $3.95(3.68)$ & $4.37(4.16)$ \\
\hline
\end{tabular}

の閉曲面が初めて現れるポテンシャル值を調べ，(2) 式に よる文字列全体の誘導場の強さの平均を求めた.

\section{4. 検 証 結 果}

最初に，心理実験結果の信頼性を検証するため，19名の 被験者をランダムに 10 名と 9 名の 2 群 $(\mathrm{A}, \mathrm{B})$ に分け, 評 価した 36 個の各文字列について，A，B群ごとに心理実験 で得られた主観評価結果の平均を求め， A， B 群間の相関 を調べた。図6(a) は紙に呈示した場合について，横軸に $\mathrm{A}$ 群，縦軸に $\mathrm{B}$ 群の主観評価の平均をとった散布図の例で ある。図中の直線は回㷌直線で，相関係数は 0.972 と高い. 図 6(a) の例を含め他の紙に呈示した場合，およびCRTに 呈示して被験者をいろいろな 2 群に分けた場合を含め，相 関係数は 0.925 から 0.972 (平均 0.948 ）の高い相関が得ら れた。このことから，任意の文字列に対する読み易さの主 観評価は，個人ごとにほほ一定であると考えられる。

次に，光源によって文字列に対する主観評価の傾向が異 なるか検証する。図 6(b) は 36 個の各文字列について，19 名の被験者全員の主観評価の平均を, 横軸に CRT, 縦軸 に紙で文字列を呈示した結果をとった散布図である，相関 係数は 0.964 と高い.このことから, 文字列に対する主観 評価は光源によって大きく異ならないと考えられる.

続いて, 読み易さの主観評価結果を示す。表 1 は, 文字 の大きさ，文字間隔の異なる図 4 の 3 つの各基本文字列に ついて, CRT (括弧内は紙) に呈示した場合の被験者全員

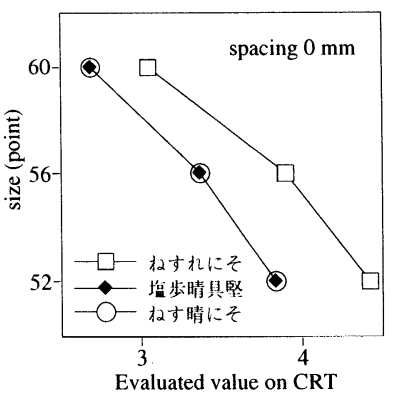

(a)

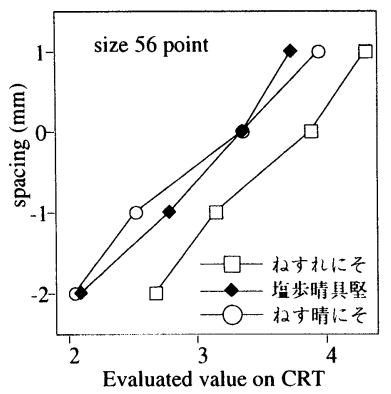

(b)
図 7 検証結果 (2)

Examing results (2)

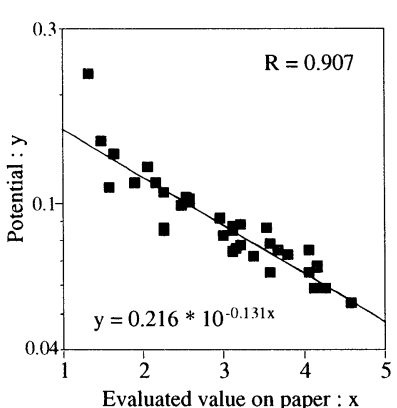

(a)

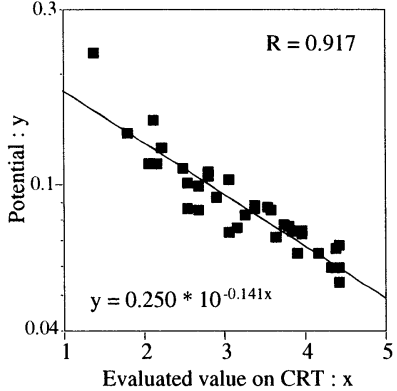

(b)
図 8 検証結果 (3)

Examing results (3).

の主観評価の平均を示した表である．図 7(a) は文字間隔 が $0 \mathrm{~mm}$ の場合, 図 4 の 3 つの各基本文字列について, 横 軸にCRTに呈示した場合の被験者全員の主観評価の平均, 縦軸に文字の大きさ（ポイント数）をとって比較したグラ フ例である. 表 1 および図 $7(\mathrm{a})$ を含めた他の例から, 文字 間隔が同じ場合，文字が小さくなると文字列が読み易くな ることがわかる。図 7(b) は文字の大きさが 56 ポイントの 場合，横軸にCRTに呈示した場合の被験者全員の主観評 価の平均, 縦軸に文字間隔 $(\mathrm{mm})$ をとって比較したグラ フ例である. 表 1 および図 7(b) を含めた他の例から, 文 字の大きさが同じ場合, 文字間隔が広がると読み易くなる ことがわかる．また，表 1 および図 7 を含めた他の例から， 図 4(a)のすべて仮名の文字列は, 同じ文字の大きさ, 文 字間隔の他の文字列より読み易いことがわかる。このよう に, 従来, 文字列の状態の表現に使われてきた文字種, 文 字の大きさ，文字間隔と文字列の読み易さには関連性が認 められるので, これら 3 要素の組合せにより文字列のおお よその読み易さを示すことができると考えられる。

図 8 は, 横軸に被験者全員の主観評価の平均, 縦軸に (2) 式による文字列全体の誘導場の平均を (a) は紙，(b) は CRT で呈示した場合をとった散布図である，誘導場の強さ は指数関数的に変化するため, 常用対数をとる変数変換に より相関関係を直線的にした上で相関係数を求めた。図 8 より，相関係数は 0.907 (紙), 0.917 (CRT) と高く, (2) 式による誘導場の強さの平均は, 文字の読み易さの心理実 


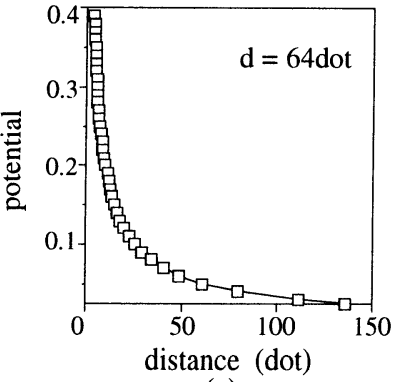

(a)

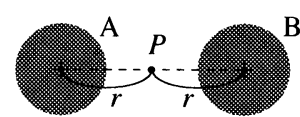

(b)

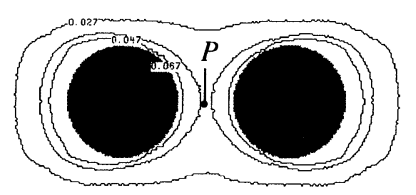

(c)
図 9 円における誘導場の平衡

Equilibrant point of Induction field by circles.

験結果とよく合致している。そして, 誘導場の強さの平均 は, 文字種, 文字の大きさ, 文字間隔が異なる任意の文字 列の状態を 1 つの值で示すことができるので, 文字列の読 み易さを一意に表現する指標に使えると考えられる。

\section{5. 文字列を構成する文字による文字列の誘導場の 予測}

\subsection{2 文字間の誘導場による予測}

以上のように，いろいろな大きさや間隔の文字列の誘導 場を計算, (2) 式による誘導場の強さの平均を求めて, 文字 列の読み易さの心理実験結果と照合すれば, 読み易い状態 を決められると考えられる。しかし，(1) 式による文字列 全体の誘導場の計算は, 画素を検出するための走査を広範 囲な文字列画像について行う必要がある上, 個々の文字を 囲む誘導場の閉曲線の検出は, ポテンシャル值を徐々に変 化させながら行うため時間がかかるという問題がある11).

複数のパターン全体が形成する誘導場は, 基本的に個々 のパターンが形成する誘導場の和である ${ }^{15)}$. そして, 誘導 場は遮蔽された部分の影響は受けない15)ので, $n$ 個の文字 から構成される文字列における, 隣接する $i, i+1$ 番目 の文字間につくられる誘導場の分布は, 元の文字列から $i$,

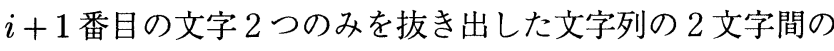
誘導場の分布で近似できると考えられる.すなわち, 個々 の文字に分離する誘導場の強さは, 隣接する 2 文字の組合 せごとに考えればよい.そこで，最初に文字パターンとし て非常に単純化した円について検討する。

まず，単独で存在する円の誘導場は，(1) 式より円の周 辺に同心円状に分布するので, 円の誘導場の強さ $m$ は, 円 の直径 $d$ と円の中心からの距離 $r$ の関数で表される.

$$
m=f(d, r)
$$

図 9(a) は，(1) 式より計算，計測した直径 $64 \operatorname{dot}$ の円の 誘導場の分布を, 縦軸にポテンシャル值, 横軸に円弧から

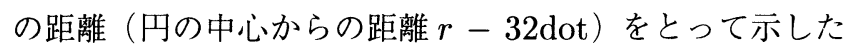
例である. 図 9(a) の例のように，実際にいろいろな直径 の円の誘導場を計測して (3) 式の関数を決定することがで きる。

次に, 図 9(b) のように, 等しい直径 $d$ の円 $\mathrm{A}, \mathrm{B}$ を中

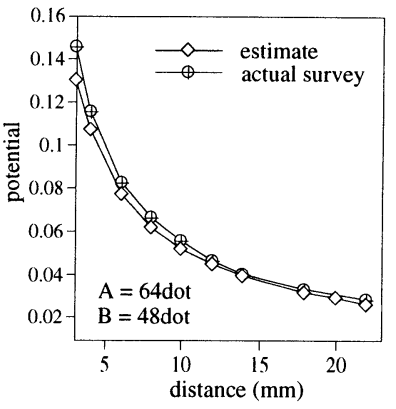

(a)

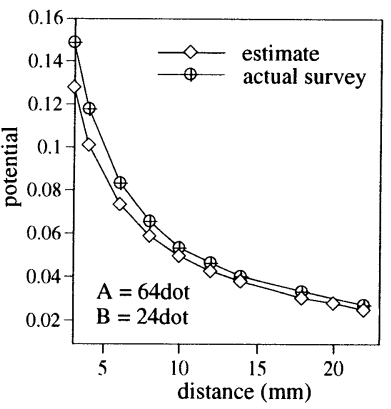

(b)
図 10 门の誘導場の予測 Estimate of Induction field by circles.

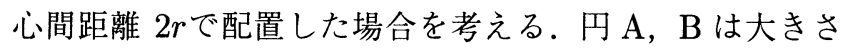
が同じなので，(3) 式は円 A, B 共に等しい. よって, 図 9 (c) の誘導場の分布例のように, 中点 $\mathrm{P}$ ( 円 $\mathrm{A}$ および $\mathrm{B}$ の中心から距離 $r$ ）を境に個々の文字を分離する誘導場の 閉曲線が存在する。したがって，円 A，Bを個々に囲む誘 導場の閉曲線の強さは, 中点 $\mathrm{P}$ の誘導場の強さ $M_{p}$ に等し い. 円 $\mathrm{A}, \mathrm{B}$ が単独で存在する場合の誘導場の強さを $m$ とすると, 誘導場は重ね合わせ ${ }^{15)}$ だら, 円 $\mathrm{A}, \mathrm{B}$ を図 9(b) のように並べた場合の中点 $\mathrm{P}$ における誘導場の強さ は $M_{p}=2 m$ である. 誘導場の強さは距離の 2 乗に反比例 する ${ }^{15)}$ から, 円 $\mathrm{A}, \mathrm{B}$ を中心間距離 $2 r$ で並べた場合, $M_{p}$ は円 A（または B）が単独で存在する場合の円 A（または B）の中心から距離 $2^{2} r$ の誘導場の強さに等しい.

$$
M_{p}=f_{A}\left(d, 2^{2} r\right)
$$

円の大きさが異なる場合 $\left(d_{A}>d_{B}\right)$, 円 $\mathrm{A}, \mathrm{B}$ の誘導 場の分布は異なる. 円 $\mathrm{A}, \mathrm{B}$ が単独で存在する場合の円の 中心から距離 $r$ の誘導場の強さを $m_{A}, m_{B}$ とすれば, 誘導 場の強さは距離の 2 乗に反比例する ${ }^{15)}$ から, $m_{A}, m_{B}$ の比 の平方根だけ中点 $\mathrm{P}$ が円 $\mathrm{A}$ の中心から距離 $r^{\prime}$ に移動する.

$$
r^{\prime}=r \sqrt{m_{A} / m_{B}}
$$

したがって，大きさの異なる円 $\mathrm{A}, \mathrm{B}$ を分離する誘導場の 強さ $M_{p}$ は (4) 式から

$$
M_{p}=f_{A}\left(d_{A}, 2^{2} r^{\prime}\right)
$$

(6) 式に，(5)，(3) 式を代入して $r^{\prime}$ を消去すると

$$
M_{p}=f_{A}\left(d_{A}, 2^{2} r \sqrt{\frac{f_{A}\left(d_{A}, r\right)}{f_{B}\left(d_{B}, r\right)}}\right)
$$

図 10(a) は, 円 A の直径が 64 dot, 円 B が $48 \operatorname{dot}$ の場 合, 図 10(b) は円 A が 64 dot, 円 B が $24 \operatorname{dot}$ の場合につ いて, 円 $\mathrm{A}, \mathrm{B}$ の中心間距離 $(\mathrm{mm})$ を横軸に, ポテンシャ ル值を縦軸にとって, 個々の文字を囲む誘導場の閉曲線が 最初に現れるポテンシャル值の (7) 式による予測と, 円 $\mathrm{A}$, $\mathrm{B}$ を配置して (1) 式で計算した誘導場の実測を比較したグ ラフの例である. 図 10 の例を含め, 他の大きさの円の組 


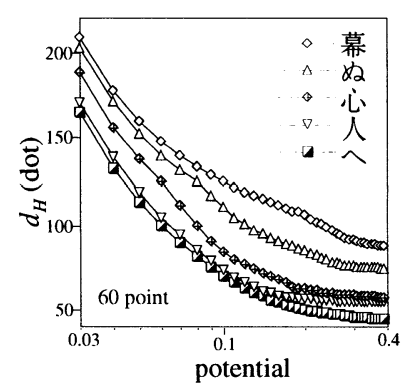

(a)

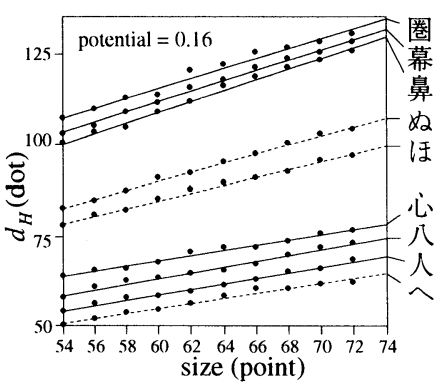

(b)
図 11 円相当径 $d_{H}$ の測定例

Analysis results of Heywoud diameter $d_{H}$.

合せも予測と実測はよく一致している。このことから， 2 つの文字の列が個々の文字に分離する誘導場の強さは，時 間のかかる (1) 式による文字列全体の誘導場の計算, 測定 をせずに，あらかじめ求めてある文字が単独で存在する場 合の誘導場の分布から，簡単に計算できると考えられる.

\section{2 文字の誘導場の予測}

円の誘導場の分布は円である. そして，文字の誘導場の 分布も文字に近い部分を除いて，誘導場の分布の大部分は 円で近似できると考えられるので，誘導場の分布をあるポ テンシャル值における等ポテンシャル面の面積 $A$ と等しい 面積をもつ円の直径 (円相当径) $d_{H}{ }^{21)}$ で表現する.

$$
d_{H}=\sqrt{4 A / \pi}
$$

図 11(a) は，文字種別に文字の大きさが 60 ポイントの 場合の円相当径（画素数）を縦軸に，ポテンシャル值を横 軸に示した例である．図 11(a) の例を含め，他の大きさの 場合も，ポテンシャル值が大きくなると円相当径が急速に 小さくなる．図 $11(\mathrm{~b})$ は文字種別にポテンシャル值 0.16 の 場合の円相当径を縦軸に, 文字の大きさを横軸に示した例 である．図 11(b) の例を含め，他のポテンシャル值の場合 も，円相当径は文字の大きさに比例する。このように，あ る文字種の誘導場の強さ $m$ は, 文字の大きさ $P$ (ポイン 卜数）と円相当径 $d_{H}$ の関数で表現できると考えられる.

$$
m=g\left(P, d_{H}\right)
$$

(9) 式は (3) 式と同様に, 図 11 の例のようにいろいろな文 字種の誘導場を計算，計測して決定することができる。

次に，隣接する 2 文字の位置関係を外接正方形を基準に 定義する．図 12(a)のように，2つの文字 A，Bの外接正 方形が間隔 $d$ で平行に配列しているとする。文字 $\mathrm{A}, \mathrm{B}$ の 大きさ $P_{A}, P_{B}$ (ポイント数) は, 各文字の外接正方形の 一辺の長さと等しい. 文字 $\mathrm{A}, \mathrm{B}$ の誘導場の分布が等しい と仮定すると, 文字 $\mathrm{A}, \mathrm{B}$ の外接正方形の中心を $O_{A}, O_{B}$ とすれば，円と同様に $\overline{O_{A} O_{B}}$ の中点 $\mathrm{P}$ では文字 $\mathrm{A}, \mathrm{B}$ の 誘導場の強さが等しくなる。 $O_{A}, O_{B}$ から外接正方形にお ろした垂線の足までの長さを $r_{A}=P_{A} / 2, r_{B}=P_{B} / 2$ と すると, $O_{A}$ から中点 $\mathrm{P}$ までの距離 $r$ は

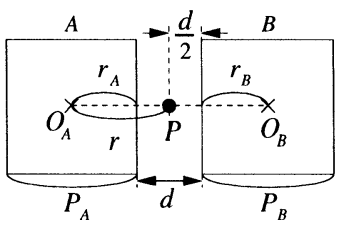

(a)

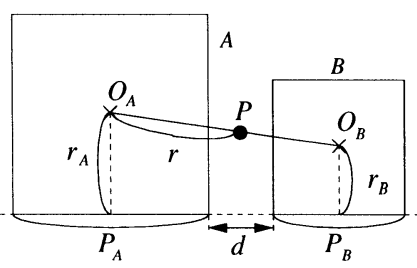

(b)
図 12 文字の位置関係

Position of characters.

$$
r=\frac{1}{2}\left(r_{A}+r_{B}+d\right)
$$

実際には図 11(b) の例のように，文字 A，B が同じ大き さでも誘導場の分布は異なるので, 円と同様に文字 A, B が単独で存在する場合の, 各文字の誘導場の強さに比例し て中点 $\mathrm{P}$ は移動する. (7), (9) 式より, 移動した中点 $\mathrm{P}$ に おける誘導場の強さ $M_{p}$ は

$$
M_{p}=g_{A}\left(P_{A}, 2 r \sqrt{\frac{g_{A}\left(P_{A}, r / 2\right)}{g_{B}\left(P_{B}, r / 2\right)}}\right)
$$

よって，(10), (11) 式から $M_{p}$ が計算できる.

図 12(b) のように文字 A, B の大きさが異なる場合 $\left(P_{A}>P_{B}\right)$, 一般に外接正方形の底辺はベースラインに 揃えることが多いので, $\overline{O_{A} O_{B}}$ は外接正方形と平行ではな い. 文字 $\mathrm{A}, \mathrm{B}$ の誘導場の分布が等しいと仮定すると, $O_{A}$ から中点 $\mathrm{P}$ までの距離 $r$ は

$$
r=\frac{1}{2} \sqrt{\left(r_{A}-r_{B}\right)^{2}+\left(r_{A}+r_{B}+d\right)^{2}}
$$

実際には文字 A，B の誘導場の分布は異なるので，図 12(a) と同様に，(11), (12) 式より誘導場の強さを計算する.

\section{3 検 証}

図 4 の 1 つの基本文字列について, 図 5 と同じ要領で, 文字間隔が $-2,-1,0,1,2 \mathrm{~mm} の 5$ 種類, 大きさが 72 , $68,64,60,56$ ポイントの 5 種類の 25 種類, 合計 75 個 の文字列を用意した。ただし, 図 4(c) の「晴」のみ文字の 大きさは 72 ポイント固定とする. 文字の読み易さの主観 評価実験と同様に，まず，用意した文字列の誘導場を (1) 式より計算, 個々の文字を囲む誘導場の閉曲面が初めて現 れるポテンシャル值を調べ, 文字列全体の誘導場の強さの 平均を (2) 式より求めた。次に, 図 4 の全文字種について, 大きさが $72,68,64,60,56$ ポイントの文字が単独で存 在する場合の誘導場を計算, ポテンシャル值が 0.01 から 0.001 ずつ 0.399 までの円相当径を (8) 式より求めて (9) 式 を決定した。これらのデー夕を基に(10), (11)，(12) 式を 用いて, 文字 $\mathrm{A}$ を $i$ 番目, 文字 $\mathrm{B}$ を $i+1$ 番目の文字とし て個々の文字を囲む誘導場の閉曲線のポテンシャル値を計 算, 文字列全体の誘導場の強さの平均を (2) 式より求めた.

図 13(a) は，75 個の各文字列の (2) 式による文字列全体 の誘導場の強さの平均について, 文字列の誘導場を計算し た実測を横軸に，個々の文字の誘導場の分布による予測を 


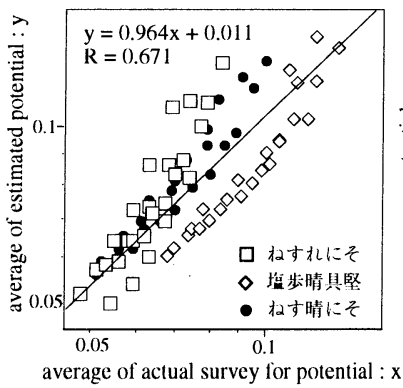

(a)

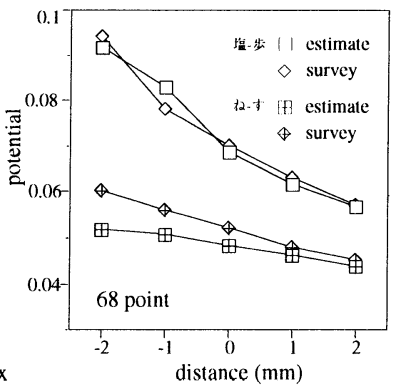

(b)
図 13 実験結果

Experimental results.

縦軸にとった散布図である. 図中の直線は回帰直線で, 予 測と実測が一致する理想の傾き 1.0 に近い 0.964 である. 図 13(b) は，文字の大きさが 68 ポイントの場合，文字間隔 ( $\mathrm{mm})$ を横軸，ポテンシャル值を縦軸にとって，図 4(a) の文字列「対すにれそ」の「ね」と「す」，および図 4(b) の文字列「塩歩晴具堅」の「塩」と「歩」を個別に囲む誘 導場の閉曲線のポテンシャル值について, 個々の文字の誘 導場の分布からの予測と実測を比較した例である。図 13 の例を含めた，他の条件での予測と実測の比較より，予測 は実測に近いことから, 文字の誘導場の分布を円相当径で 表現することによって，個々の文字を個別に囲む誘導場の 強さを計算により予測することができると考えられる。

\section{4 読み易い文字列の状態の決定}

図 14 は，大きさの等しい同じ文字種を 2 個以上，等間 隔で並べた文字列を紙に呈示した場合, 視距離 $1 \mathrm{~m}$ で 5 段 階評価の読み易い状態 4 にするための文字の大きさ（ポイ ント数）を横軸に, 隣接する 2 文字の中心間距離 $(\mathrm{mm})$ を縦軸に示した例である。読み易い状態 4 のポテンシャル 值 0.065 （図 8(a) から計算）を実現する文字間隔を, 各文 字種, 大きさの文字が単独で存在する場合の円相当径の測 定結果および (10), (11) 式から計算した. 図 14 から, 大 きい文字は小さい文字より, 漢字の文字列は仮名の文字列 よりも広い文字間隔が必要なことがわかる。これは, 表 1 および図 7 の例で示された文字列の読み易さの傾向が, 誘 導場の分布で説明できることを示している. 以上のように, 個々の文字の誘導場の分布から, 時間がかかる文字列全体 の誘導場の計算, 測定を行わずに, 読み易くするための設 定すべき具体的な文字種, 文字の大きさ, 文字間隔が簡単 に計算できると考えられる。

\section{6. 考察}

\section{1 誘導場による文字列の読み易さの説明}

図 8 の結果から, 文字列の読み易さの指標として着目し た，文字列の誘導場における個々の文字を囲む誘導場の閉 曲線の強さが，人間による読み易さとよく一致することが 示された。すなわち, 個々の文字の誘導場の干渉の強さが 文字列の読み易さと関連することが示唆されていたが，干

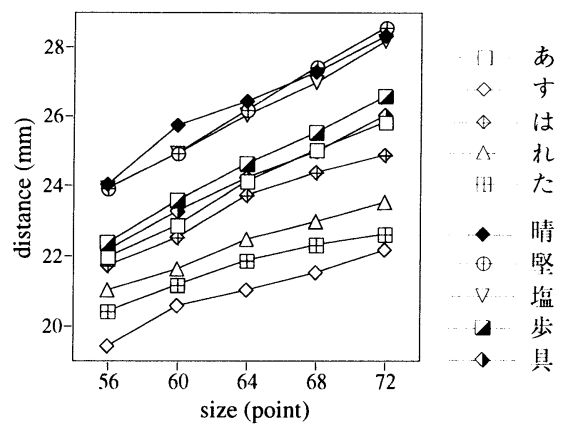

図 14 最適な文字間隔の予測

Expectation of suitable character distance.

渉の程度は (2) 式による文字列全体の誘導場の強さの平均 で表現でき，実際に人間の文字列の読み易さと対応してい ることが明らかになった。このことは，多くの心理実験で 妥当性が確認され，文字パターンの類似性などいろいろな 視知覚の説明がされている視覚の誘導場は, さらに文字の 読み易さも説明できる有効な概念であることが示された.

\section{2 読み易さの客観的指標}

表 1, 図 7 から，文字列の状態を決める文字種，文字の 大きさ，文字間隔によって，文字列の読み易さをおおよそ 推定できると考えられる。しかし，文字列の読み易さを表 すには，図 7 の例のように，これら文字列の状態を示す 3 要素の組合せが必要であり，一意に読み易さを決めること は容易ではない。

一方, 図 8 から, 誘導場の強さを用いれば, 読み易い文 字列の状態を一意に表すことが可能であり, 誘導場の強さ は人間の読み易さとよく一致している。すなわち，文字種， 文字の大きさ，文字間隔が異なっても，表示したい文字列 の誘導場の強さを計算すれば, 文字列の読み易さを誘導場 の強さのみで決定できると考えられる．このことから，誘 導場は読み易い文字列の表示を行うために有効な客観的指 標を提供できると考えられる。

\section{3 読み易い文字列の状態の決定}

図 13 から, 文字列の読み易さの指標となる誘導場の強 さは, 時問がかかる文字列全体の誘導場の計算, 測定をせ ずに，文字列を構成する文字の 2 文字ずつの組について， 各組の文字種が独立に存在する場合の誘導場の分布から， 簡単に計算によって予測できることが示された。そして， 図 14 から，表示したい文字列の文字種の組合せが決まれ ば，読み易い文字列にするための文字の大きさ，文字間隔 が，経験によらず具体的に決定できる。この方法を用いれ ば，例えば，携帯端末では限られた表示面積で見易さをで きるだけ落とさず多くの文字を効率良く，また高精細な八 イビジョンでは，より多くの文字をより読み易くするプロ ポーショナル表示などが可能になると考えられる.

\section{4 課 題}

図 13 のポテンシャル值が大きい場合の仮名などのよう に，文字の誘導場の分布から予測した個々の文字を囲む誘 
導場の強さと実測の違いが 0.01 程度以上大きい場合があ る。これは，文字，特に仮名は漢字に比べ長いストローク などの影響により誘導場の分布が複雑になり, 円では誘導 場の分布が充分記述できず, 誘導場の強さの予測に誤差が 生じたものと考えられる。そこで，例えば，等ポテンシャ ル面の形状が円で近似できるか円形度や複雑度 ${ }^{21)}$ で判断し, 複雑な場合, 楕円で誘導場の分布を近似して, 個々の文字 を囲む誘導場の強さを予測するなどの方法が考えられる.

\section{7.むすび}

文字列の読み易さの客観的指標として, 文字列を構成す る個々の文字を囲む, 視覚の誘導場の閉曲線の強さに着目 し，実際に読み易さの心理実験結果とよく合致することが 示された。この結果からここれまでいろいろな人間の視知 覚を説明してきた誘導場は，さらに有効な概念であると考 えられる。そして, 誘導場は表示したい文字列の誘導場の 強さを計算すれば，文字種，文字の大きさ，文字間隔が異 なる任意の文字列の読み易さを一意に決定できることか ら，誘導場は人間に優しい読み易い文字列の表示を行うた めに有効な指標を提供できると考えられる。また，時間が かかる文字列全体の誘導場を計算, 測定をせずに, 文字が 単独で存在する場合の誘導場の分布から, 文字列を構成す る個々の文字を分離する誘導場の強さが, 計算によって簡 単に求められることが示された。この方法による，携帯端 末などでの読み易い文字列の効率的なプロポーショナル表 示などの応用が考えられる，今後，文字の読み易さの指標 を利用した手書き文字の切り出しを検討する予定である.

本論文の心理実験に御指導, 御協力して頂いた豊橋技術 科学大学 臼井支朗教授, 石榑康雄氏, 臼井研究室の皆様, 愛知県立大学 小濱剛氏, 本稿をまとめるにあたり御助言頂 いた NHK 大阪放送局技術部 山田光穗氏に感謝致します。

\section{〔文献〕}

1）塚田敢, 湊幸衛: “レタリングと文字認識”, 心理学評論, 11, pp.140-155 (1968)

2）和田正信編：“印写工学 III 画像形成論”, pp.335-340, 共立出版 (1969)

3）和田正信編：“印写工学 VI 視覚と心理, 記録”, pp.24-26, 共立出 版 (1974)

4）米山恒雄, 神山忠信, 井沢孝次：“図形パターンの検出感度によるディス プレイ表示文字の評価”，テレビ誌， 50，11，pp.1768-1774（1996）

5） NHK 放送技術研究所：“より多くの情報を読みやすく”, http://www.strl.nhk.or.jp/open97/ex/z503/index-j.html (1997)

6) “コマーシャル・フォト・シリーズ クリエイターのための印刷ガイド ブック 1 基礎編”, pp.48-49, 玄光社（1993）

7）奥村晴彦：“LaTEX 美文書作成入門”, pp.1-10, 技術評論社 (1991)

8）大西誠一郎：“異なった文脈の中に位置づけられた文字の認知について”, Jap. J. Psychol., 38, 1, pp.25-32 (1967)

9) 横瀬善正：“形の心理学”, 名古屋大学出版会 (1986)

10) Yokose Z. : "A Study on Character-Patterns Based Upon the Theory of Psychological Potential Field", Japanese Phychological Research, 12, 1, pp.18-25 (1970)

11）長石道博：“視覚の誘導場を用いた手書き文字の切出し”，信学論， J 76-D-II, 9, pp.1948-1956 (1993)

12）深水義之, 吉田登美男, 小谷津孝明, 野田健一, 諸角建：“横瀬「場の 理論」のコンピュータシミュレーションー景観の図形喼識の立場か らの解明と評価に関する研究 (1)”, デザイン学研究, 92, pp.43-50 (1992)

13）厳壮志, 八村広三郎：“視覚ポテンシャルを用いる図形の最適配置”, 情

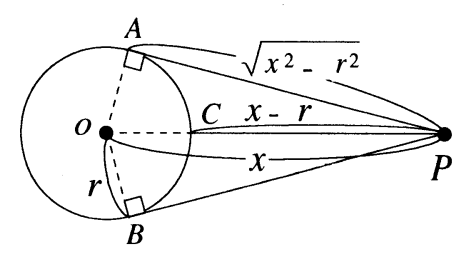

(a)

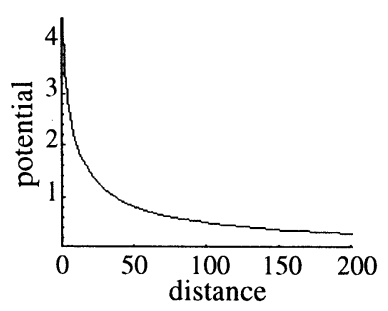

(b)
付·図 1 円がつくる誘導場 Induction field by circle.

処学第 46 回全大, 9C-8 (1993)

14）三好正純, 下塩義文, 古賀広昭：“視喾的に均整のとれた図形配置の視 覚の誘導場による評価”，平成 10 年信学総全大, A-15-5（1998）

15）長石道博：“視覚の誘導場モデルを用いたパターン認識時の心理実験結 果の検証”，テレビ誌， 50，12，pp.1965-1973 (1996)

16）野澤晨：“空間と時間”, 第 5 章, 彰国社 (1975)

17) M. Shimomura, K. Yokosawa: "Identification of Kanji and Kana character within Japanese words", Perception \& Psychophysics, 50, pp.19-27 (1991)

18）池田光男：“眼はなにを見ているか一視覚系の情報処理一”, 第 3 章, 自然丵書 8 , 平凡社 (1988)

19）神部尚武: “読みの眼球運動と読みの過程”, 国立国語研究所報告 85, 研 究報告集 7, pp.29-66 (1986)

20）斎田真也: “眼球運動の実験心理学”, 第 8 章, 名古屋大学出版会 (1993)

21）長谷川純一, 舆水大和, 中山晶, 横井茂樹: “画像処理の基本技法一技 法入門編一”, 技術評論社 (1986)

\section{〈付 録〉}

\section{円の誘導場の分布の関数}

円の誘導場は, (3) 式の形式で表現できることを示す．付 •図 $1(\mathrm{a})$ のように, 半径 $r$ の円の中心 $O$ から距離 $x$ の点 $\mathrm{P}$ における誘導場の強さ $M_{p}$ は, 点 $\mathrm{P}$ から円に引いた接線を $P A, P B$, 円と $P O$ の交点を $C$ とすると, 点 $\mathrm{P}$ から発し た光が当たる円弧 $\widehat{A C B}$ のみで決まる ${ }^{15)}$ から文献 9)より

$$
\begin{aligned}
M_{p} & =\int_{P A}^{P B} \frac{1}{x} d x \\
& =2 \int_{P A}^{P C} \frac{1}{x} d x=2[\log |x|]_{x-r}^{\sqrt{x^{2}-r^{2}}} \\
& =2 \log \sqrt{\frac{x+r}{x-r}}
\end{aligned}
$$

円の直径 $d=2 r, x-r=l$ とおくと(付·1) 式は

$$
M_{p}=2 \log \sqrt{1+d / l}
$$

付·図 1(b) は，(付·2) 式で計算した $d=64$ における $M_{p}$ を縦軸に, 円弧からの距離 $l$ を横軸にとったグラフの例で, $d=64 \operatorname{dot}$ の円を実測した図 9(a)の分布に近い.このよう に, 円の誘導場は円の直径と距離の関数で表される.

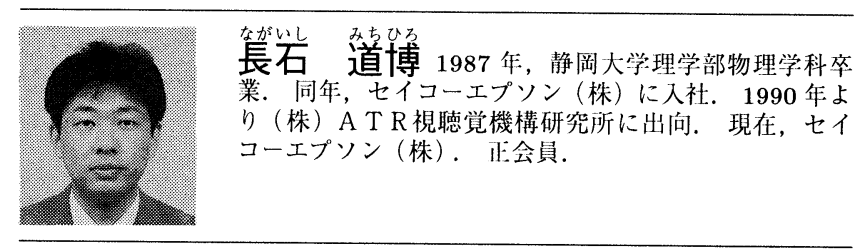

